\title{
WHAT WILL BE LEFT OF THE PRIMARY FORESTS IN ECUADOR?
}

\author{
Alexander Hirtz \\ Mañosca 434, Quito, Ecuador•Sachalaichu@yahoo.com
}

\begin{abstract}
Ecuador is among the smallest countries of South America (250,000 square kilometers) but has the highest density of human population with the highest network of primary and secondary roads, which also explains why Ecuador has the highest slash-and-burn ratio per capita in America (about 250,000 hectares per year). Over $20 \%$ of the country's surface has been declared as natural private and government reserves, where at least $2 / 3$ of the area is totally inaccessible and has never been botanized. Thus, a large percentage of the approximate 1000 endemic orchid species described to date for Ecuador are probably not growing in these reserves. The remaining $80 \%$ of land is subdivided into 843,000 land ownerships, of which only $4 \%$ are parcels over 50 hectares. It can be concluded that no primary forests outside the reserves will survive the near future and respective endemic species will become extinct in nature. Ex-situ conservation is imperative.
\end{abstract}

Resumen. Ecuador es uno de los países más pequeños de América del Sur (250,000 kilómetros cuadrados) pero que tiene la más alta densidad de población humana con la red más alta de caminos primarios y secundarios, lo cual explica porqué Ecuador tiene la relación más alta per capita de corte y quema en América (aproximadamente 250,000 hectáreas por año). En exceso de un 20\% de la superficie del país ha sido declarada como reservas naturales privadas o del gobierno, donde por lo menos $2 / 3$ del área es totalmente inaccesible y nunca ha sido estudiadas botánicamente. Así, un gran porcentaje de las aproximadamente 1000 especies endémicas de orquídeas descritas hasta la fecha para el Ecuador, probablemente no estén creciendo en estas reservas. El $80 \%$ restante de la tierra se encuentra subdividida en 843,000 propiedades, de las cuales el 4\% son parcelas de más de 50 hectáreas. Se puede concluir que ningún bosque primario que se encuentre fuera de las reservas podrá sobrevivir en el futuro cercano y que las respectivas especies endémicas se extinguirán en la naturaleza. Por lo tanto la conservación ex-situ resulta imperativa.

KEY wORDS: Conservation, forest, Ecuador

On December 14, 2008, the New York Times Magazine published an article (Risen, 2008) related to the rights of plants under the new Constitution of Ecuador. The article stated that Ecuador vaulted to the forefront of international ecopolitics when it became the first country to extend constitutional rights to nature, which includes the right to the maintenance and regeneration of its vital cycles, structures, functions, and evolutionary processes. The implications go much further, arguably granting broad protections to simple life forms such as algae and even bacteria.

In order to comprehend the challenges we face in the future, some important and relevant topics within the new constitution should be understood. The new constitution covers the rights of nature and its restoration in several chapters and at least 34 extensive articles. Also covered are Ecuadorians' rights for a healthy, ecologically sustainable environment free of contamination and in harmony with nature. The State guarantees that, on a fair basis, citizens and communities will permanently have access to good quality water, air, soil, and to the benefits of the underground resources - otherwise known as the "natural patrimony." Environmental preservation including ecosystem conservation, all components of biodiversity, the integrity of genetic patrimony, the prevention of environmental damages, and the restoration of degraded natural areas - is declared to be of public interest.

Chapter VII is devoted entirely to the rights that nature has under this new Constitution, where Article 71 states the following: where life is generated and reproduced in nature, its existence has to be respected in its entirety, securing and maintaining its vital cycles, 
structures, functions, and evolutionary processes. Any person or community may make demands to government authorities for the immediate fulfillment of these rights given to nature. Article 72 states that whatever party is responsible for damages to the environment must also be financially accountable for its restoration. They are also responsible to pay indemnities to whatever communities were affected by the damage. Articles 73 and 396 obligate the State to take the precautionary measures or restrictions to all activities that might lead to the extinction of species, the destruction of ecosystems or the permanent alteration of natural cycles. In case of doubt, even without scientific evidence for potential damage, the State has to adopt effective protective measures. Article 74 gives individuals and communities the right to benefit from the environment and its natural wealth to allow for better living. This is an interesting article in the Constitution because it implies that people and communities may, for example, collect orchids or insects in the wild for commercialization. This application of the article is a total contradiction to the current laws and regulations established by the Ministry of Environment.

Further on, a whole chapter is devoted to biodiversity and natural resources. In various Articles, it states that all environmental policies are obligatory for the citizens, organizations, and the State at all administrative levels. In case of doubt, the executive and judicial systems have to vote in favor of nature. Every person in the daily process of production, distribution, and use of goods and services assumes the responsibility to prevent any environmental impact, mitigate and restore any damages caused by his actions, and maintain a permanent environmental management program. Legal actions to prosecute and sanction the culprit for environmental damages cannot be waived under any circumstances.

Article 397 establishes the following: in case of environmental damage, the State will act immediately and subsidize the guarantees required for the restoration of health to the damaged ecosystem. The State will sanction not only the party responsible for damaging the ecosystem, but it will also make the public servants in charge of the environmental controls responsible for not preventing the damages in the first place. To enforce the above, any citizen or community may exercise legal actions against parties who might endanger the health of any ecosystem, which includes water, air, soil, and the life forms within them. The accused party is responsible for proving its innocence. The government will also regulate and limit the landholdings in fragile ecosystems, which include the páramos, wetlands, cloud forests, tropical dry and wet forests, and mangroves. In relation to landholdings, Article 282 outlaws large landholdings. While Bolivia is considering reducing landholdings to between 5,000 and 10,000 hectares, in Ecuador the new legislation is considering limiting the landholdings to 800 hectares. It will also confiscate land that is not producing, which will raise questions from landowners who want to preserve natural habitats. In Article 411, the State guarantees the conservation, recuperation, and integral management of all water resources, water basins, and everything related to water cycles. In Article 414, the State will adopt adequate measures to mitigate the effects of global climate change by limiting gas emissions, deforestation, and air contamination. It will take measures for the conservation of the forests and other vegetation and protect the civilian population.

The title of this lecture is "What Will Be Left of the Primary Forests in Ecuador?" Under the new Constitution, all primary forests are protected, and any damage has to be restored immediately by all levels of government. Article 426 states that applicability and observance of this Constitution is in force immediately, where the authorities may not delay any action described in the new Constitution by claiming that the bylaws and regulations are not yet in place or invoking any other excuse. It is generally agreed that about 300,000 hectares of primary ecosystems are burned down every year in Ecuador. Any person, organization or community may now demand that the State immediately restore any destruction and punish the culprits.

In his article published by the New York Times Magazine, Risen (2008) pointed out that it's uncertain how, exactly, a country as poor as Ecuador can protect these rights and how it can protect Pachamama or Mother Universe and the ecosystem as a whole. With a surface of only $283,561 \mathrm{~km} 2$, Ecuador is second smallest among the countries of South America, after Uruguay. Ecuador has the highest density of human population in South America with 49 inhabitants per 
$\mathrm{km} 2$, whereas Peru, a country five times larger than Ecuador, has 23 inhabitants per $\mathrm{km} 2$, and Bolivia, a country four times larger, has only 8.3 inhabitants per $\mathrm{km} 2$. Ecuador has 14 million inhabitants living in the country and another three million working abroad. About $37 \%$ live in rural areas. The birthrate is $1.5 \%$, which means that every year 210,000 Ecuadorians turn 18 and enter the work force. It is difficult for any government to secure 210,000 additional jobs per year, and Ecuador has to assume that, of the three million working abroad, many will return to Ecuador over the next two years because they lost their jobs in the global economic crisis. Ecuador has the highest network of primary and secondary roads in South America, adding up to at least 40,000 kilometers. Ecuador is only 700 kilometers long, north to south, from the border of Colombia to the border of Peru. The growing capital city of Quito already covers 7\% of this distance.

These area constraints and population density factors are the main reasons why Ecuador has the highest ratio of slash-and-burn to total surface area of any country in the Americas; we lose around 300,000 hectares of primary forests per year. Because of the high density of plants growing on trees, about 20 to 30 million plants are burned every hour. The likelihood of our generation seeing a dramatic decrease in the rate of deforestation is near impossible. Decreeing a new constitution where nature has almost unlimited rights is a futile effort, because it will only slow down economic growth and force the poor to move into the remaining forests. The rural population would have to educated in record time and given realistic alternatives for their survival in the next five years, because in 10 years there will be no forests left to save. In the efforts to save nature, most conservationists fight only mining and oil companies and rarely address the real problem, which is extensive subsistence agriculture practiced by the poor. The efforts of a handful of concerned botanists trying to stop the ancestral practice of slashand-burn agriculture will not change the fact that it is an enormously successful adaptation to the rigors and constraints of the tropical forest.

Ecuador is fortunate to have over $20 \%$ of its surface declared as natural private and government reserves, within which at least two thirds of the areas are totally inaccessible and have not even been botanized. Unfortunately, a paragraph in Article 405 of the new
Constitution states that neither a foreigner nor any foreign organization may own title to any property or concessions in protected areas. This will undoubtedly raise legal issues in cases where foreigners or NGOs have previously purchased land and had it declared as a protected area, only to lose it under the new Constitution.

A large percentage of the approximate 1,000 endemic orchid species described to date for Ecuador are probably not growing in the currently established natural reserves. Almost all of these described species were made from collections on private property next to the road. The remaining $80 \%$ of land in Ecuador is subdivided into 843,000 land ownerships, where only $4 \%$ are parcels over 50 hectares. This $4 \%$ of landholdings will soon be subdivided under the new Constitution, probably into areas no larger than 500800 hectares. Officials of the current government have also stated they will not tolerate unused land and give it to people in need. That implies that whoever has any primary forest left had better replace it with pasture, as was customary in the 1960s and 1970s under the Agrarian Reform. Of course, this threat directly contradicts the new Constitution.

It can be concluded that no primary forests outside the reserves will survive in the near future, and respective endemic species in these forests will become extinct in nature. To make matters worse, even if we optimistically assume that farmers and loggers will not impact the protected areas in the coming decades, we cannot blindly believe that the orchid species living in these forests will survive the oncoming climate changes, regional acid rains, and dehydration from the surrounding desertification. To secure the biodiversity of the protected areas, we cannot ask for more than what is already written in the new Constitution. But it is clear that the other forests or biodiversity on private property will not be around for much longer. Therefore, ex-situ conservation measures have to be taken more seriously, particularly with the implementation of botanical gardens distributed at all levels throughout the country.

Tourism directed to bird-watching, butterfly farms or orchid photo safaris is one of the main methods to sustain biodiversity; local communities will quickly learn that this will bring business and well-being to their people. Many small communities have already 
started to plant native species in their gardens or public places, particularly orchids and bromeliads that they rescued from fallen trees. The Ministry of Environment is assisting such communities in their efforts to turn this into a legal activity, where the growers of these botanic gardens obtain the respective permits and authorizations. The communities of the "Nor-Occidente" around Mindo and San Miguel de los Bancos are good examples.

This year the Orchid Society of Quito has decided to patronize the implementation of the orchid garden "Sisa Ricsina, Flowering in Community." This project was proposed and will be managed by a network of six native Kichwa communities in the province of Napo that are currently forming the Mushuk Sisa Foundation. These communities are already well organized and successful in community-operated tourism. Their botanical garden, highlighting orchids, will be established next to the Río Jatun Yacu.
We of the Quito Orchid Society are dedicated to strengthening initiatives that will protect our environment and educate our people. We take it as our duty to navigate through the restrictions and freedoms in Ecuador's new Constitution. With pride and diligence we will accept the challenge and succeed in helping orchids survive and be enjoyed by everyone. It is our hope that other orchid societies both here in Ecuador and abroad will be able to face our collective challenge and help sponsor small communities in their nascent botanical garden projects. These communities are our keys to success and the future of orchid tourism and orchid ex-situ conservation.

LiteratuRe Cited

Risen, C. 2008. Plants' rights. New York Times Magazine, December 14, 2008. 